\title{
Strategies of Behavior Voluntary Regulation of Primary Schoolchildren in Health and Disease
}

\author{
Elena A. Cherenevaa, Irina Ya. Stoyanova ${ }^{b}$ \\ and Olga L. Belyaeva ${ }^{a *}$ \\ ${ }^{a}$ Krasnoyarsk State Pedagogical University named after V.P. Astafiev \\ Krasnoyarsk, Russian Federation \\ ${ }^{b}$ Tomsk National Research Medical Center \\ of the Russian Academy of Sciences \\ National Research Tomsk State University \\ Tomsk, Russian Federation
}

Received 03.07.2019, received in revised form 15.10.2019, accepted 25.10.2019

\begin{abstract}
The development of voluntary behavior of children with intellectual disabilities is a complex and long-term process that requires a special comprehensive behavioral therapy, which should be aimed at correcting disadaptive patterns of behavior. The purpose of the article is a comparative clinical and psychological analysis of voluntary behavior of children with intellectual disabilities and identification of the main mechanisms of its origin.

The article presents the research results of the strategies of voluntary behavior of primary schoolchildren in health and with mental disabilities. It distinguishes the levels of voluntary regulation and cognitive strategies of behavior in health and disease.

The study has resulted in developing a structural and functional model of voluntary regulation of behavior of children with mental disorders; a concept of dynamic study of voluntary behavior of primary schoolchildren in health and disease, which is reflected in the interrelated levels of personal organization; the assessment of voluntary regulation levels of primary schoolchildren in health and disease.

The article also presents the results of the studies of voluntary behavior strategies of primary schoolchildren in health and with mental disabilities, establishes the main determinants of its origin, and defines the levels of voluntary regulation and cognitive strategies of behavior in health and disease.
\end{abstract}

Keywords: voluntary behavior, intellectual disability, strategies of voluntary behavior regulation.

Research area: medical psychology.

(C) Siberian Federal University. All rights reserved

* Corresponding author E-mail address: elen_korn@bk.ru 
Citation: Chereneva, E.A., Stoyanova, I.Ya., Belyaeva, O.L. (2019). Strategies of behavior voluntary regulation of primary schoolchildren in health and disease. J. Sib. Fed. Univ. Humanit. Soc. Sci., 15(4), 526-536. DOI: 10.17516/1997-1370-0476.

\section{Introduction}

The problem of the study of mental regulation in childhood is one of the urgent problems of our time. Today's trends in the development of modern society indicate the emergence of a large number of mental disorders caused by various etiopathogenetic factors. Some of them are the increased level of mental tension, high levels of stress and frustration across the population, caused by socio-economic problems, the increased level of birth of children with mental disorders, the formation of mental deviations in childhood. This is evidenced by data statistics (Chereneva, E.A., Gutkevich, E.V., 2017). Therefore, in our opinion, the relevance of the study of mental regulation in children in health and disease is obvious, not only because it is one of the indicators of the emotional-personal sphere, but also because it is the main mechanism for the formation of behavioral voluntariness and socio-psychological adaptation in adulthood.

In theory and practice of psychological science, the researchers are still interested in studying the determinants of voluntary behavior as a factor in the formation of the emotional-personal sphere in childhood and an indicator of an individual's socio-psychological adaptation in adult life. Of particular interest to us is the generalization of voluntary behavior in childhood through the cognitive strategies used by the individual. The term of "cognitive strategies" in clinical practice is used quite widely in the aspects of cognitive-behavioral therapy. We will use this term while analyzing voluntary behavior. In our case, voluntariness is a mental formation that unites cognitive, behavioral, emotionally focused social strategies, changes in the social environment, including the features of the use of cognitive strategies, in solving behavioral tasks that undergo cognitive processing. As Philip Kendall (2002) points out, cognitive strategies are not inherited from parents through the genetic code, but are acquired through experience, through observa- tion and through interactions with other people (Chereneva, E.A., 2014). This is of particular research interest, since in our opinion, the level of voluntary regulation does not fully depend on the level of intelligence. Of course, the features of higher nervous activity and the level of cognitive development affect the formation of the overall regulation of behavior, the formation of goals, objectives and aspects of the control of voluntariness process implementation, but it is necessary to keep in mind the multidimensionality of voluntariness. For example, one of the components is our emotional states, both positive (Daniel \& Lucas, 1999) and negative ones, which affect our cognitive and behavioral tasks.

\section{Theoretical framework}

We have identified the key approaches on the basis of the concept of interdisciplinary research, which allow studying the mechanisms of voluntary behavior. Let us specify the main ones, which contain many grounds that allow developing the methodological concept of the modern understanding of voluntariness and knowledge of people in general.

In personality psychology this is a systematic approach to the study of personality (P.K. Anokhin, B.G. Ananyev, V.A. Barabanshchikov, D.N. Zavalishina, A.V. Karpov, B.F. Lomov, V.D. Shadrikov, E.G. Yudin); a subject-activity approach (K.A. Abulkhanova-Slavskaya, B.G. Ananyev, A.B. Brushlinsky, E.A.Klimov, A.N. Leontyev, B.F. Lomov, S.L. Rubinstein); the concept of self-regulation of the subject's activity (B.G. Ananiev, L.I. Antsiferova, B.V. Zeigarnik, V.P. Zinchenko, E.A. Klimov, O.A. Konopkin, A.A. Krylov, G.S. Nikiforov, D.A. Oshanin, V.A. Petrovsky); the theory of open self-organizing psychological systems (V.E. Klochko, O.M. Krasnorotsev and others), a person's system of values as a dynamic system (M.S. Yanitsky).

Modern studies in psychology, which allow revealing the problem of research are cop- 
ing strategies in stress psychology (E.I. Rasskazova, T.O. Gordeeva); the formation of social competence as a mechanism for strengthening mental health of the younger generation (N.V. Kalinina, O.A. Semenova); the development of voluntary regulation of activity in children of primary school age (O.A. Semenova, R.I. Machinskaya); cognitive styles, about the nature of the individual mind (M.A. Kholodnaya); conscious self-regulation as a metasystem of psychological resources for achieving goals and human self-development (V.I. Morosanova).

In medical (clinical) psychology it is theories of the modern family in the aspect of the psychology of personal health (E.V. Gutkevich), in the general theory of rigidity by G.V. Zalevsky, in the studies carried out across these theories (E.V. Galazhinsky, I.O. Gileva, I.A. Tepleneva, O.B. Sheptenko, and others), the development of criteria for assessing mental health. The psychodynamic concept of personality (Z. Freud, A. Freud, A. Adler, G. Jung, E. Erickson, C. Rogers, K. Horney, E. Fromm); understanding of an attitude as one of the psychological mechanisms affecting the activity of the individual, presented in the studies of D.N. Uznadze, Sh.A. Nadirashvili, Sh.N. Chkhartishvili, and his followers, A.G. Asmolov, V.P. Zinchenko, S.I. Kuryachy and others.

In correctional psychology this is the theory of the unity of the laws of normal and abnormal child development (T.A. Vlasova, L.S. Vygotsky, A.N Graborov, G.M. Dulnev, V.P. Kashchenko, V.I. Lubovsky, A.R. Luria, M.S. Pevzner, V.G. Petrova, T.V. Rozanova, E.A. Strebeleva, Zh.I. Shif, etc.); the unity of age patterns in the normal and abnormal mental development of the child and the role of subjective and objective factors in this process (L.I. Bozhovich, L.S. Vygotsky, V.V. Davydov, A.V. Zaporozhets, R.E. Levina, V.I. Lubovsky, V.V. Ul'enkova, D. B. Elkonin, and others), the ideas of cultural-historical psychology by L.S. Vygotsky, modern ideas about the types and stages of psychosocial development (M.Yu. Kondratiev, D.I. Feldstein), a system-activity approach to assessing the complex reality of development (A.G. Asmolov).

\section{Statement of the problem}

Behavioral disorders associated with intellectual development disorders (hereinafter referred to as IDD) are frequent causes that complicate the socio-psychological adaptation of students in this category in adulthood. The late identification of their nature, the lack of special preventive and corrective programs lead to the fact that behavioral disorders of children with IDD in adolescence and adulthood often reach the level of criminal manifestation.

Therefore, in modern conditions, the role of research on the voluntary regulation of behavior and the main mechanisms of its formation in the prevention of behavioral disturbances and deviations in the emotional-personal sphere, which provide a psychological focus in the system of preventing social deviations, has sharply increased. The issues of behavioral disorders of children and adolescents with IDD were considered in connection with the development of adequate methods of correctional and educational process and social and labor adaptation (V.V. Korkunov, Mirsky, Dulnev, Lauzhikas). And only in recent decades scientists have heightened their the interest to study the actual problem of behavioral disorders of mentally retarded children and adolescents as a mechanism for successful social adaptation (Sh.N. Chkhartishvili, M.G. Tsartsize, E.A. Chereneva). At the same time, the success of social adaptation and integration of children with mental underdevelopment into society is determined not only by the depth of cognitive impairments, but also by the behavioral characteristics of this category of children with significantly weakened abilities to adapt to social requirements.

We have studied the mechanisms of cognitive strategies of voluntary behavior of primary schoolchildren in health and disease (intellectual disabilities). The concept of dynamic studying the voluntary behavior of primary schoolchildren in health and disease is reflected in the interrelated levels of personal organization. The levels developed by us determine not only the characteristics and their dynamic structure of self-regulation, but also the peculiarities of the individual's emotional and personal experience that influences the formation 
of the personality as a whole. We distinguish the following levels of voluntary regulation and their structural components: personality-semantic, cognitive, regulatory.

\section{Methods}

The concept of dynamic studying the voluntary behavior of primary schoolchildren in health and disease is reflected in the interrelated levels of personal organization. The levels developed by us determine not only the characteristics and their dynamic structure of self-regulation, but also the peculiarities of the individual's emotional and personal experience that influences the formation of the personality as a whole. We distinguish the following levels of voluntary regulation and their structural components: personality-semantic, cognitive, regulatory.

The assessment of the levels of voluntary regulation among primary schoolchildren in health and disease are based on the following parameters:

- Self-esteem, level of aspirations, attitudes, protective mechanisms of behavior personal-semantic level;

- The level of intelligence development, dynamic properties of thinking (rigidity, stiffness, inertia, sticking (perseveration)) - cognitive level;

- The relationship of behavior with speech (speech functions: regulating function, planning function, behavior control (external and internal) - regulatory level).

We have identified the levels and parameters of the evaluation of voluntary behavior, which are based on the axes of diagnosis: clinical, pathopsychological and socio-psychological. A comprehensive system of evaluation of voluntary regulation of behavior generalizes derivatives: cognitive strategies in voluntary regulation and features of interactions with other people.

\section{Discussion}

The study was conducted in Russia, Krasnoyarsk and Krasnoyarsk Krai. At this stage, groups of primary schoolchildren who had no significant difficulties in learning (healthy subjects) and groups of subjects with reduced intellectual activity at various levels were completed: students with intellectual disabilities had slight mental retardation (MDP) and slight intellectual disability. The qualitative characteristic of the intellectual defect corresponds to the clinical diagnoses of ICD-10 (DSM IV): F 80.82, F 81, F 70). We formed three groups of subjects: NID (subjects with normal intellectual development), NID1 (subjects with mental retardation - mentally retarded), and NID2 (subjects with slight intellectual disabilities). Two age groups were formed - 8-9-yearold children and 10-11-year-old children, each group included 76 people. The total number of subjects was 456 8-11-year-old students. The parents (mothers) of the subjects in the amount of 456 people were also tested.

In order to evaluate the strategies of the studied group of subjects, we used the following methods: longitudinal observation method, conversation, a method of qualitative and quantitative analysis of data and such methods as Achenbach Questionnaire for Parents to Study the Adaptation Problems of the Subjects and the observation map developed by us, which allows evaluating the levels of voluntary behavior and a type of cognitive strategy.

During the study, we found the data that complement the clinical and psychological features of the voluntary behavior of primary schoolchildren in health and disease. Besides, they reveal the mechanisms of voluntariness formation in the context of the emotional-personal sphere formation of the studied student groups. Let us characterize the table data. To process the results of the study, we used the criterion $\varphi^{*}$ that is Fisher angle transformation (Table 1-2). The studies of intergroup differences of 10-11-year-old subjects show significant differences between subjects with normal mental development and slight intellectual disabilities in almost all scales (except for alienation and disobedience scales).

In the course of the study, we developed an observation map, which allows us to determine the level of voluntary regulation and the type of cognitive strategy of the studied student group. We have identified the following components of voluntariness: goal-setting, regulation of emotional states, control of actions, 
Elena A. Chereneva, Irina Ya. Stoyanova,.. Strategies of Behavior Voluntary Regulation of Primary Schoolchildren...

Table 1. Analysis of intergroup differences in adaptation indicators on the Achenbach questionnaire (8-9-year-olds)

\begin{tabular}{|c|c|c|c|c|c|c|c|c|c|}
\hline \multirow{3}{*}{ Scales } & \multicolumn{9}{|c|}{ Groups / difference accuracy } \\
\hline & \multicolumn{2}{|c|}{ IDD } & \multicolumn{2}{|c|}{ IDD1 } & \multicolumn{2}{|c|}{ IDD2 } & \multirow{2}{*}{$\begin{array}{l}\text { IDD - } \\
\text { IDD1 }\end{array}$} & \multirow{2}{*}{$\begin{array}{l}\text { IDD - } \\
\text { IDD2 }\end{array}$} & \multirow{2}{*}{$\begin{array}{c}\text { IDD1 - } \\
\text { IDD2 }\end{array}$} \\
\hline & $\mathrm{n}=76$ & $\%$ & $\mathrm{n}=76$ & $\%$ & $\mathrm{n}=76$ & $\%$ & & & \\
\hline Emotional reactivity & 38 & 50 & 35 & 46,1 & 25 & 32,9 & 0,481 & $2,151^{*}$ & $1,671^{*}$ \\
\hline Anxiety & 46 & 60,5 & 38 & 50,0 & 20 & 26,3 & 1,301 & $4,346^{* * *}$ & $3,045^{* * *}$ \\
\hline Somatic complaints & 59 & 77,6 & 30 & 39,5 & 22 & 28,9 & $4,913 * * *$ & $6,294 * * *$ & 1,381 \\
\hline Alienation & 19 & 25,0 & 18 & 23,7 & 15 & 19,7 & 0,185 & 0,783 & 0,598 \\
\hline Sleep problems & 40 & 52,6 & 31 & 40,8 & 19 & 25,0 & 1,461 & $3,551 * * *$ & $2,090 *$ \\
\hline Attention problems & 36 & 47,4 & 40 & 52,6 & 44 & 57,9 & 0,641 & 1,295 & 0,653 \\
\hline Aggressive behavior & 21 & 27,6 & 29 & 38,2 & 47 & 61,8 & 1,399 & $4,334 * * *$ & $2,934 * * *$ \\
\hline Affective problems & 34 & 44,7 & 21 & 27,6 & 16 & 21,1 & $2,213^{*}$ & $3,144 * * *$ & 0,931 \\
\hline Anxiety & 51 & 67,1 & 32 & 42,1 & 24 & 31,6 & $3,132 * * *$ & $4,475 * * *$ & 1,344 \\
\hline Perverse problems & 21 & 27,6 & 29 & 38,2 & 30 & 39,5 & 1,399 & 1,560 & 0,160 \\
\hline Hyperactivity & 33 & 43,4 & 47 & 61,8 & 21 & 27,6 & $2,275^{*}$ & $2,047 *$ & $4,321 * * *$ \\
\hline Disobedience & 28 & 36,8 & 41 & 53,9 & 36 & 47,4 & $2,127^{*}$ & 1,325 & 0,801 \\
\hline Others & 17 & 22,4 & 27 & 35,5 & 39 & 51,3 & $1,794 *$ & $3,766^{* * *}$ & $1,973^{*}$ \\
\hline
\end{tabular}

* differences are significant at the level of $p \leqslant 0.05\left(\varphi^{*}=1.64\right)$;

${ }^{* *}$ differences are significant at the level of $p \leqslant 0.01\left(\varphi^{*}=2.31\right)$;

${ }^{* * *}$ differences are significant at the level of $p \leqslant 0,001\left(\varphi^{*}=2.81\right)$.

Table 2. Analysis of intergroup differences in adaptation indicators on the Achenbach questionnaire (10-11-year-olds)

\begin{tabular}{|c|c|c|c|c|c|c|c|c|c|}
\hline \multirow{3}{*}{ Scales } & \multicolumn{9}{|c|}{ Groups / difference accuracy } \\
\hline & \multicolumn{2}{|c|}{ IDD } & \multicolumn{2}{|c|}{ IDD1 } & \multicolumn{2}{|c|}{ IDD2 } & \multirow{2}{*}{$\begin{array}{l}\text { IDD - } \\
\text { IDD1 }\end{array}$} & \multirow{2}{*}{$\begin{array}{l}\text { IDD - } \\
\text { IDD2 }\end{array}$} & \multirow{2}{*}{$\begin{array}{c}\text { IDD1 - } \\
\text { IDD2 }\end{array}$} \\
\hline & $\mathrm{n}=76$ & $\%$ & $\mathrm{n}=76$ & $\%$ & $\mathrm{n}=76$ & $\%$ & & & \\
\hline Emotional reactivity & 30 & 39,5 & 28 & 36,8 & 20 & 26,3 & 0,339 & $1,738^{*}$ & 1,399 \\
\hline Anxiety & 35 & 46,1 & 29 & 38,2 & 12 & 15,8 & 0,986 & $4,161^{* * *}$ & $3,175^{* * *}$ \\
\hline Somatic complaints & 39 & 51,3 & 21 & 27,6 & 14 & 18,4 & $3,027 * * *$ & $4,395 * * *$ & 1,368 \\
\hline Alienation & 28 & 36,8 & 27 & 35,5 & 29 & 38,2 & 0,166 & 0,179 & 0,345 \\
\hline Sleep problems & 24 & 31,6 & 27 & 35,5 & 10 & 13,2 & 0,512 & $2,774 * *$ & $3,286^{* * * *}$ \\
\hline Attention problems & 30 & 39,5 & 38 & 50,0 & 47 & 61,8 & 1,307 & $2,774 * *$ & 1,467 \\
\hline Aggressive behavior & 25 & 32,9 & 30 & 39,5 & 39 & 51,3 & 0,845 & $2,312^{* *}$ & 1,467 \\
\hline Affective problems & 25 & 32,9 & 18 & 23,7 & 12 & 15,8 & 1,264 & $2,490 * *$ & 1,227 \\
\hline Anxiety & 40 & 52,6 & 26 & 34,2 & 20 & 26,3 & $2,305^{*}$ & $3,366^{* * *}$ & 1,060 \\
\hline Perverse problems & 20 & 26,3 & 30 & 39,5 & 32 & 42,1 & $1,738^{*}$ & $2,065^{*}$ & 0,327 \\
\hline Hyperactivity & 30 & 39,5 & 28 & 36,8 & 19 & 25,0 & 0,339 & $1,923 *$ & 1,584 \\
\hline Disobedience & 32 & 42,1 & 39 & 51,3 & 37 & 48,7 & 1,140 & 0,820 & 0,321 \\
\hline Others & 28 & 36,8 & 33 & 43,4 & 38 & 50,0 & 0,826 & $1,646^{*}$ & 0,820 \\
\hline
\end{tabular}

${ }^{*}$ differences are significant at the level of $p \leqslant 0.05\left(\varphi^{*}=1.64\right)$;

${ }^{* *}$ differences are significant at the level of $p \leqslant 0.01\left(\varphi^{*}=2.31\right)$;

${ }^{* * *}$ differences are significant at the level of $p \leqslant 0,001\left(\varphi^{*}=2.81\right)$. 
achievement of the goal of action, defined the criteria characterizing the components of voluntariness: dynamism, stability, activity, initiative and independence of manifestation. We have also recorded the parameters of voluntary behavior, which had persisted in the subjects for at least 3 months. The level of voluntary behavior and cognitive strategies were assessed according to the scores obtained. We have identified high (60-50 points) and average (30-40 points) levels, which correspond to adaptive strategies, and below average (40-30 points) and low (20-30 points) levels, which correspond to non-adaptive strategies.

On the basis of the obtained results, we have identified the strategies of voluntary regulation in childhood.

Adaptive strategies - high and average levels of voluntary regulation. This strategy characterizes the subjects with the use of the variety of effective models of behavior that lead to productive activities and the achievement of goals. Children in this group have the skill of pre-planning, subsequent regulation and control of action. Children of this group, as a rule, have the skill of self-organization and self-discipline. Often their actions have high motivation and awareness in achieving goals. They can regulate their emotional states, overcome frustration. The stage of control of action is characterized by the formedness of the skill of all stages of control (pre-emptive, current and final). There is criticality, comparison of the results obtained with the obtained sample, emotionally-colored assessment in achieving the goals at all the stages of the cognitive strategy. They are able to show willpower when performing difficult tasks, worry, if something goes wrong. Children of this group can be proactive, can defend their point of view when building a cognitive strategy.

High level of behavior regulation. At this level, primary schoolchildren at a high level consistently manifest all the components of a cognitive strategy: from setting to obtaining a goal and critically evaluating the result of an activity. Children have a high, socially motivated motivation to achieve their goals. As a rule, children of this group have a higher cognitive level of development, are physically more en- during, capable of restructuring previously formed patterns of behavior and attitudes. They are characterized by persistence, stubbornness, perseverance, capable of self-organization and self-regulation of behavior. There is an external programming of actions: they pronounce future actions or comment them.

Average level of behavior regulation. The subjects of this group have a harmonious combination of many factors that allow them to achieve their goals. For example, with a certain lack of skills at the stage of goal-setting and controlling actions, children in this category can manifest a high level of self-organization, discipline, blocking of emotionally adverse factors (stage of regulation of emotional states). The subjects of this group may perform additional erroneous or unnecessary actions, but, in general, they are capable of correcting errors in the process of activity and achieve their goals and results.

Non-adaptive strategies - below average and low levels. This kind of strategy characterizes the subjects with the presence of a variety of ineffective behaviors that do not lead to productive achievement of the goal. As a rule, children of this group have a deficit in preliminary planning, subsequent regulation and control of action. Often their actions may have initially high motivation and vigor, but in the process of activity (especially long-lasting), the actions taken have no effect. Often, the change in the tone of voluntary activity is associated with a high level of anxiety, the presence of a high level of frustration, and the presence of destructive attitudes, which does not allow overcoming an obstacle at the stage of regulating emotional states. The stage of action control is characterized by a violation or loss of the skill of current and final control (provided there is prior control). At the stage of achieving the goal, children often experience a violation of criticality in the assessment of the result or a refusal to accept it. They are able to show willpower when performing difficult tasks, worry if something goes wrong.

Below average level. Children of this level initially have potential prerequisites in goal-setting, as well as an understanding in building strategies for achieving results. There 
are errors in the planning and control of actions. It should be noted that the subjects of this group have a high level of influence of the emotional-personal sphere on the process of voluntary behavior. Even with a high level of cognitive development, the subjects of this group show a tendency of a greater influence of the emotional-personal sphere on the organization of the whole activity, rather than the operational side of the activity. Children show good performance results of activity with an adult's constant monitoring and assistance during the whole voluntary process, can be proactive. To a greater extent, an adult's assistance may have an emotional or regulatory effect rather than an operating one.

Low level. Children of this level initially have deficiencies for self-construction in goal-setting, as well as in the ability to build strategies for achieving results. This trend is also characteristic of children with high cognitive development. Independent motive factors of voluntary activity are not constructive and are subject to the position of an adult. The subjects of this group do not have the formed skills and abilities in setting goals and planning in building the strategy of a voluntary process. As a rule, there is a high rigidity and stiffness of mental processes, due to a greater degree of individual emotional and personal experience. This feature reflects the nature of parent-child relations, which form the dependence and limitations in the repertoire of behavior patterns. There is a deficit both in the motivational, operational and regulatory side of a voluntary process that has a social nature (features of parent-child relations, the presence of previous negative experiences of an independent choice, etc.). With great difficulty, they are able to show willpower when performing difficult tasks, they worry, if something goes wrong but cannot cope with an obstacle on their own. All components of a cognitive strategy goal-setting to obtaining results fail. They are self-critical, they can easily plan their own activities, but they can give up the job they have started, without bringing it to the end. There is an elementary initiative in the activity. They are not capable of open confrontation, but take offence for long. The distribution of the subjects in groups is shown in Tables 3 and 4.

\section{Conclusion}

Thus, the relevance of the problem under study is determined both by the trends in the development of scientific knowledge and by the existing needs of socio-psychological and clinical practice. The study of voluntary behavior in childhood with normal and impaired intellectual development is an important direction, as it allows revealing not only the mechanisms of mental regulation, but also the mechanisms of formation of emotional-personal development. The obtained data will allow solving the most important theoretical and practical problem that requires actual research and development. We have found that:

Table 3. Analysis of intergroup differences in the formedness of the levels of voluntary regulation on the assessment map for voluntary regulation cognitive strategies (8-9-year-olds)

\begin{tabular}{|c|c|c|c|c|c|c|}
\hline \multirow{3}{*}{ Scales } & \multicolumn{6}{|c|}{ Groups } \\
\hline & \multicolumn{2}{|c|}{ IDD } & \multicolumn{2}{|c|}{ IDD1 } & \multicolumn{2}{|c|}{ IDD2 } \\
\hline & $\mathrm{n}=76$ & $\%$ & $\mathrm{n}=76$ & $\%$ & $\mathrm{n}=76$ & $\%$ \\
\hline Adaptive strategies & 35 & 47,3 & 16 & 21,0 & 4 & 5,2 \\
\hline High & 10 & 13,1 & 1 & 1,3 & 0 & 0 \\
\hline Average & 25 & 33,0 & 10 & 13.1 & 4 & 5,2 \\
\hline Non-adaptive strategies & 41 & 53,9 & 60 & 78,9 & 72 & 94,7 \\
\hline Below average & 25 & 33,0 & 40 & 52,6 & 45 & 59,2 \\
\hline Low & 16 & 21,0 & 20 & 26,3 & 27 & 35,5 \\
\hline
\end{tabular}


Elena A. Chereneva, Irina Ya. Stoyanova,.. Strategies of Behavior Voluntary Regulation of Primary Schoolchildren...

Table 4. Analysis of intergroup differences in the formedness of the levels of voluntary regulation on the assessment map for voluntary regulation cognitive strategies (10-11-year-olds)

\begin{tabular}{|c|c|c|c|c|c|c|}
\hline \multirow{3}{*}{ Scales } & \multicolumn{6}{|c|}{ Groups } \\
\hline & \multicolumn{2}{|c|}{ NID } & \multicolumn{2}{|c|}{ NID1 } & \multicolumn{2}{|c|}{ NID2 } \\
\hline & $\mathrm{n}=76$ & $\%$ & $\mathrm{n}=76$ & $\%$ & $\mathrm{n}=76$ & $\%$ \\
\hline Adaptive strategies & 45 & 59,2 & 44 & 43,2 & 15 & 19,7 \\
\hline High & 18 & 23,6 & 9 & 11,8 & 1 & 1,3 \\
\hline Average & 25 & 32,8 & 35 & 46,0 & 14 & 26,3 \\
\hline Non-adaptive strategies & 31 & 40,7 & 32 & 56,5 & 61 & 80,3 \\
\hline Below average & 24 & 31,5 & 20 & 26,3 & 38 & 50,0 \\
\hline Low & 7 & 9,2 & 12 & 15,8 & 23 & 30,3 \\
\hline
\end{tabular}

1. The formation of voluntary regulation of a child's behavior is a continuous, multi-deterministic process, represented as an individual subject-object trajectory of the development of the individual, which is reflected through the system of child-parent relations.

2. The formation of voluntary behavior regulation in primary schoolchildren in health and disease has fundamentally the same factors of social and psychological genesis, the mechanisms of formation and determination of voluntary regulation in health and disease.

3. Cognitive strategies of voluntary regulation of behavior in childhood affect the peculiarities of interactions with other people and are more dependent on individual emotional-personal experience and level of intellectual development.

Cognitive skills are directly dependent on the level of development of intelligence, the correlation coefficient is +0.75 . This means that as the level of intelligence increases, the success of the cognitive strategy of voluntary behavior increases.

4. Cognitive strategies of voluntary behavior are directly dependent on social experience and the characteristics of parent-child relations, the correlation coefficient is $\mathrm{kxy}=+0.72$. This means that the formation of cognitive strategies of voluntary behavior of the subjects depends on the parental attitudes.

5. A direct strong link has been established between the formation of components of voluntary behavior and child-parent relations and partly depends on the level of intelligence, the correlation coefficient is +0.75 . This means that the higher the level of intelligence, the higher the level of the components of voluntary behavior. Besides, the higher the level of parental attitudes, the more likely the formation of the productivity of voluntary behavior components.

6. The level of intelligence influences the formation of voluntary behavior as a generalizing product of all mental activity and directly depends on the characteristics of child-parent relations and the emotional-personal sphere, the correlation coefficient is +0.68 . This means that the level of intelligence partially influences the formation of an adaptive strategy and the level of voluntary regulation.

7. Cognitive strategies of voluntary regulation of behavior in childhood directly affect the peculiarities of interactions (communication) with other people, the correlation coefficient was +0.8 . This means that the formation of interactions with other people is more dependent on individual emotional-personal experience and the level of intellectual development.

Comparative clinical and psychological studies of voluntariness in childhood in normal state and in intellectual pathology will allow:

1. Expanding the additional possibilities of understanding the mechanisms of the formation of the personality of children in health and disease, the search for additional resources for the development and correction of the emotional-personal sphere.

2. Developing modern multi-disciplinary diagnostic complexes for assessing mental reg- 
ulation in childhood and therapeutic programs for children and their families for the prevention of secondary mental disorders.

3. Developing methodological concepts of understanding the mechanisms of voluntariness with the parameters of the subjective world and their influence on the emotional-personal development in childhood and socio-psychological adaptation in adulthood.

\section{References}

Bodrov, B.A. (2006). Problema preodoleniia stressa. Chast' 2. Protsessy i resursy preodoleniia stressa [Problem of overcoming stress. Part 2. Processes and resources to overcome stress.]. In Psikhologicheskii zhurnal [Psychological Journal], 27 (2), 113-123.

Bozhovich, L.I. (1968). Lichnost' $i$ ee formirovanie $v$ detskom vozraste [Personaity and its formation in childhood]. Moscow, $64 \mathrm{p}$.

Chereneva, E.A. (2008). Samoreguliatsiia uchebnoi i vneuchebnoi deiatel'nosti u uchashchikhsia 5-6kh klassov spetsial'nykh (korrektsionnykh) shkol VIII vida [Self-regulation of educational and extracurricular activities for 5- $6^{\text {th }}$ graders of special (correctional) schools of type 8]. Krasnoyarsk State Pedagogical University named after V.P. Astafiev. 261 p.

Chereneva, E.A. (2013). Defensive mechanisms of behavior and conceptual sets in socio-psychological adaptation of children with intellectual disabilities. In Journal of Siberian Federal University. Humanities \& Social Sciences, 6 (9), 1374-1387.

Chereneva, E.A. (2014). Unconscious mechanisms of social and psychological adaptation of mentally retarded children. In Journal of Siberian Federal University. Humanities \& Social Sciences, 7 (9). $1620-1626$.

Chereneva, E.A., Cherenev, D.V. (2017). Psikhologicheskie kriterii issledovaniia lichnosti mladshikh shkol'nikov s narusheniiami intellektual'nogo razvitiia [Psychological criteria for studying the personality of primary schoolchildren with intellectual disabilities]. In Inkliuzivnoe obrazovanie v professional'nykh obrazovatel'nykh uchrezhdeniiakh. Materialy XVIII Vserossiiskoi nauchno-prakticheskoi konferentsii [Inclusive education in vocational educational institutions: problems and solutions. Proceedings of the $18^{\text {th }}$ All-Russian Research-to-Practice Conference], 209-213.

Chereneva, E.A., Gutkevich, E.V. (2017). Teoretiko-metodologicheskii analiz predposylok postroeniia kontseptsii izucheniia reguliatsii povedeniia det'mi s intellektual'nymi narusheniiami [Theoretical and methodological analysis of the preconditions for constructing a concept for studying the regulation of behavior by children with intellectual disabilities]. In Vestnik Krasnoiarskogo gosudarstvennogo pedagogicheskogo universiteta [Bulletin of Krasnoyarsk State Pedagogical University], 2 (40), 180-186.

Gersamia, E.A. (1968). Fiksirovannaia ustanovka detei-oligofrenov i nekotorye osobennosti struktury ikh psikhiki [Fixed attitude of oligophrenic children and some features of the structure of their psyche]. Tbilisi, $173 \mathrm{p}$.

Kalinina, N.V. (2001). Formirovanie sotsial'noi kompetentnosti kak mekhanizm ukrepleniia psikhicheskogo zdorov'ia podrastaiushchego pokoleniia [The formation of social competence as a mechanism for strengthening the mental health of the younger generation]. In Psikhologicheskaia nauka i obrazovanie [Psychological Science and Education], 4, 16-21.

Karelina, I.O. (2017). Psikhologicheskii i pedagogicheskii aspekty formirovaniia proizvol'noi reguliatsii emotsii u detei starshego doshkol'nogo vozrasta [Psychological and pedagogical aspects of formation of the voluntary regulation of emotions in senior preschool children]. In Aktual'naia pedagogika [Morern Pedagogy], 1, 36-44.

Kholodnaya, M.A. (2018). Kognitivnye stili. O prirode individual'nogo uma [Cognitive styles. Concerning the nature of the individual mind]. Litres, $180 \mathrm{p}$.

Padun, M.A. (2015). Reguliatsiia emotsii i ee narusheniia [Regulation of emotions and its violation]. In Psikhologicheskie issledovaniia:elektronnyi nauchnyi zhurnal [Psychological research: electronic scientific journal], 8 (39), 5-7. 
Rasskazova, E.I., \& Gordeeva, T.O. (2011). Koping-strategii v psikhologii stressa: podkhody, metody i perspektivy issledovanii [Coping strategies in the psychology of stress: approaches, methods and prospects for research]. In Psikhologicheskie issledovaniia: elektronnyi nauchnyi zhurnal [Psychological research: electronic scientific journal], 3, 4-4.

Morosanova, V.I. (2017). Osoznannaia samoreguliatsiia kak metasistema psikhologicheskikh resursov dostizheniia tselei i samorazvitiia cheloveka [Conscious self-regulation as a metasystem of psychological resources to achieve the goals and self-development of man]. In Fundamental'nye i prikladnye issledovaniia sovremennoi psihologii rezul'taty i perspektivy razvitiia [Fundamental and applied research of modern psychology: results and prospects of development], $501 \mathrm{p}$.

Sagalakova, O.A., Truevtsev, D.V. (2015). Narushenie proizvol'noi reguliatsii psikhicheskoi deiatel'nosti pri sotsial'noi trevoge $\mathrm{v}$ kontekste formirovaniia antivital'nogo i suitsidal'nogo povedeniia [Violation of voluntary regulation of mental activity during social anxiety in the context of the formation of anti-vital and suicidal behavior]. In Innovatsii v nauke [Innovations in science], 49. 93-101.

Semenova, O.A. (2007). Formirovanie proizvol'noi reguliatsii deiatel'nosti i ee mozgovykh mekhanizmov $\mathrm{v}$ ontogeneze [Formation of voluntary regulation of activity and its brain mechanisms in ontogenesis]. In Fiziologiia cheloveka [Human physiology], 33 (3), 115-127.

Semenova, O.A., Machinskaya, R.I. (2007). Razvitie proizvol'noi reguliatsii deiatel'nosti u detei mladshego shkol'nogo vozrasta [Development of activity voluntary regulation of primary schoolchildren]. In Voprosy prakticheskoi pediatrii [Practical Pediatrics Issues], 2 (6). 17-23.

Shutilina, A.A., Sagalakova, O.A. (2017). Kul'turno-spetsificheskie strategii sovladaiushchego povedeniia i kognitivnoi reguliatsii emotsii pri sotsial'noi trevoge [Cultural-specific strategies for coping behavior and cognitive regulation of emotions in social anxiety], $123 \mathrm{p}$.

Soroko, S.I., Aldasheva, A.A. (2012). Individual'nye strategii adaptatsii cheloveka v ekstremal'nykh usloviiakh [Individual strategies for human adaptation in extreme conditions]. In Fiziologiia cheloveka [Human Physiology], 38 (6), 78-79.

Trofimova, N.M., Duvanova, S.P., Trofimova, N.B., Pushkina, T.F. (2005). Osnovy spetsial'noi pedagogiki i psikhologii [Fundamentals of special pedagogy and psychology]. Piter, $210 \mathrm{p}$.

Vygotsky, L.S. (1960). Razvitie vysshikh psikhicheskikh funktsii [Development of higher mental functions]. Moscow, Academy of Pedagogical Sciences, 500 p.

Zeygarnik, B.V. (2000). Patopsikhologiia [Pathopsychology]. Moscow, April-Press, EKSMO-Press, 574 p. 


\title{
Стратегии произвольной регуляции поведения у детей младшего школьного возраста в норме и патологии
}

\author{
Е.А. Черенева ${ }^{a}$, И.Я. Стояноваб \\ ${ }^{a}$ Красноярский государственный педагогический \\ университет им. В. П. Астафьева \\ Российская Федерачия, Красноярск \\ ${ }^{6}$ Томский национальный исследовательский медицинский изентр РАН \\ Национальный исследовательский Томский государственный университет \\ Российская Федерация, Томск
}

\begin{abstract}
Аннотация. Развитие произвольного поведения у детей с нарушениями интеллектуального развития - сложный и длительный процесс, требующий специальной комплексной поведенческой терапии, которая должна быть направлена на коррекцию дезадаптивных паттернов поведения. Целями статьи являются сравнительный клинико-психологический анализ произвольного поведения у детей с нарушениями интеллектуального развития и определение основных механизмов его формирования. В статье приведены результаты исследований стратегий произвольного поведения у детей младшего школьного возраста в норме и при нарушениях интеллектуальной деятельности. Выделены уровни произвольной регуляции и когнитивные стратегии поведения в норме и патологии.

По результатам исследования разработаны: структурно-функциональная модель произвольной регуляции поведения детей с ментальными нарушениями; концепция динамического изучения произвольного поведения у детей младшего школьного возраста в норме и патологии, которая отражена во взаимосвязанных уровнях личностной организации; оценка уровней произвольной регуляции у детей младшего школьного возраста в норме и патологии.

Представлены результаты исследований стратегий произвольного поведения у детей младшего школьного возраста в норме и при нарушениях интеллектуальной деятельности. Установлены основные детерминанты их формирования. Выделены уровни произвольной регуляции и когнитивные стратегии поведения в норме и патологии.
\end{abstract}

Ключевые слова: произвольное поведение, нарушения интеллекта, стратегии произвольной регуляции поведения.

Научная специальность: 19.00.14 — медицинская психология. 